\title{
JOANNA KOMOROWSKA
}

\section{CARDINAL STEFAN WYSZYNSKI UNIVERSITY IN WARSAW}

\section{ALEXANDER, HIS TEACHER, AND THE STATUS OF PHILOSOPHY IN PLUTARCH OF CHAERONEA: AN INQUIRY INTO THE MEANING OF A CERTAIN EXCHANGE OF LETTERS ${ }^{1}$}

The principal focus of the present article is the exchange of letters quoted by Plutarch of Chaeronea, celebrated teacher and MiddlePlatonist of the first century $\mathrm{CE}$, in his equally famous bios Alexandrou, a work describing the life and deeds of the great Macedonian as juxtaposed with those of his Roman counterpart, Caesar. My aim is simple enough: to evaluate the function and meaning of said exchange in the framework of the bios, its possible cultural and moral import, and thus, its contribution to the Plutarchean portrayal of Alexander and his attitude toward philosophy. As for the authenticity of the exchange, the issue is of limited relevance in the present essay, since Plutarch very clearly considers the letters in question as authentic - for clarity's sake, however, one may add that Hadot dismisses them as a Hellenistic apocryph, intended to bolster the standing of Andronicus' redaction of Aristotelian Metaphysics ${ }^{2}$. As far the more general issue of Plutarch's employment of letters in Alexander's biography is concerned, the Aristotle letter is hardly a unique instance of such an occurrence much in keeping with his predilection for the anecdotal, Plutarch does

\footnotetext{
1 The relevant research was made possible by a statutory grant from UKSW. As for the Vita Alexandri context, I have benefited from discussions with Dr Aleksandra Klęczar (Jagiellonian University).

2 Cf. Hadot 1990: 67. For the general outline of the debate concerning the letters attributed to Aristotle, cf. Natali 1991: 149-150. For Plutarch's familiarity with the Aristotelian writings cf. Karamanolis 2006: 85-126.
} 
occasionally invoke the testimony of correspondence: as private means of communication letters are a valuable testimony to man's character and customs: thus, in the later parts of the bios, we find quotations (some paraphrased) from Alexander's correspondence with his mother, Olympias (mentioned in Alex. 39.5) or from letters exchanged between him and various officials: hence, the appearance of the Aristotle letters conforms to the more general Plutarchean usage ${ }^{3}$.

\section{THE EXCHANGE}

Plutarch's account is set against the background of the longer narrative concerned with Alexander's childhood and his education, in a series of facts and anecdotes demonstrating many and varied talents of the young conqueror ${ }^{4}$. Thus, we learn that recognizing his son's relentless ambition, but also his capacity to be guided by reason ( $\rho \alpha \delta \delta$ í $\omega \varsigma$

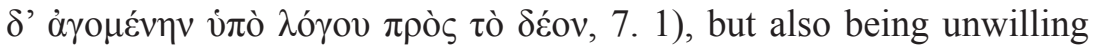
to entrust his education to more ordinary men, king Phillip sent for the most highly regarded scholar and philosopher of his era, Aristo-

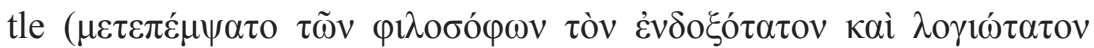

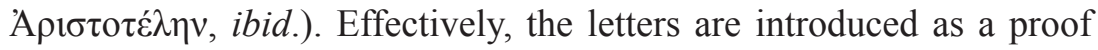
for the extent of this particular education ${ }^{5}$. As we read (Alexander 7 . $3-5)$ :

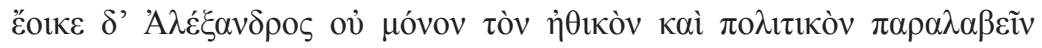

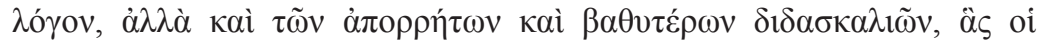

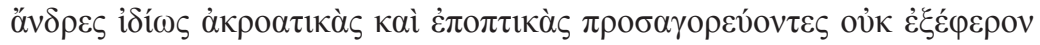

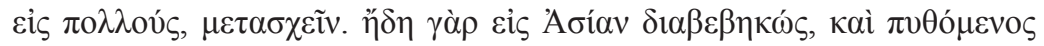

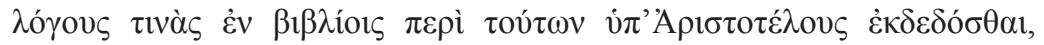

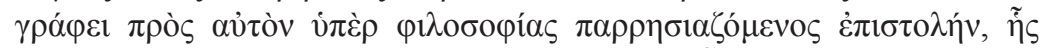

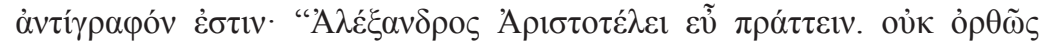

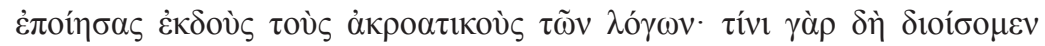

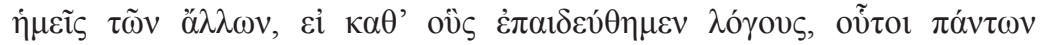

\footnotetext{
3 For the compositional issues of the Bioi cf. the overview of Van der Stockt 2014.

4 For the complexity of Alexander's nature as portrayed in Plutarch's work (with emphasis on de Alex. Fortuna) cf. Teodorsson 2008: 348.

5 For Plutarch's use of sources cf. e.g. Muccioli 2011, Ottone 2011, Hernández Goméz 2011, or the summarizing study of Schettino 2014.
} 


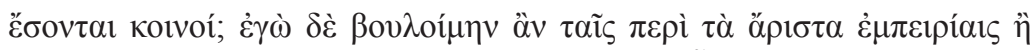

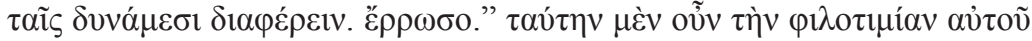

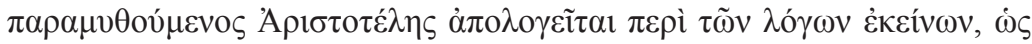

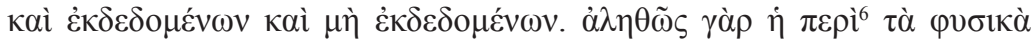

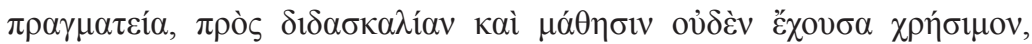

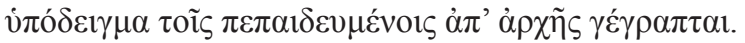

It would appear, moreover, that Alexander not only received from his master his ethical and political doctrines, but also participated in those secret and more profound teachings which philosophers designate by the special terms 'acroamatic' and 'epoptic,' and do not impart to many. For after he had already crossed into Asia, and when he learned that certain treatises on these recondite matters had been published in books by Aristotle, he wrote him a letter on behalf of philosophy, and put it in plain language. And this is a copy of the letter. 'Alexander, to Aristotle, greeting. Thou hast not done well to publish thy acroamatic doctrines; for in what shall I surpass other men if those doctrines wherein I have been trained are to be all men's common property? But I had rather excel in my acquaintance with the best things than in my power. Farewell.' Accordingly, in defending himself, Aristotle encourages this ambition of Alexander by saying that the doctrines of which he spoke were both published and not published; for in truth his treatise on metaphysics is of no use for those who would either teach or learn the science, but is written as a memorandum for those already trained therein (tr. B. Perrin).

One notes that throughout the tale the focus remains firmly on Alexander, all the 'philosophical' data being purely incidental to the central narration: the narrator aims at demonstrating Alexander's possible proficiency in philosophical studies rather than exploring the intricacies of Aristotle's teachings.

From the formal perspective we note that only one letter is quoted in its entirety as Aristotle's response is paraphrased, the choice undoubtedly improving the poikilia, variety of the narrative style and being in agreement with many other instances where Plutarch attempts to incorporate correspondence into his narration ${ }^{7}$. It is also interesting to

\footnotetext{
6 Significantly, some editions prefer $\mu \varepsilon \tau \dot{\alpha}$ : this in fact is what we find in the Loeb text constituting the basis of Perrin's translation (Loeb 1909), itself based on the editions of Sintenis (Teubner 1873-1875) and Bekker (Tauschnitz 1855-1857).

7 For Plutarch's formal consciousness as regards quotations and style of quoting cf. e.g. Bowie 2008 .
} 
note that the author manages to convey a certain impression of equal standing in the letter: Alexander writes to his master openly expressing his doubts, $\pi \alpha \rho \rho \eta \sigma \iota \alpha \zeta o ́ \mu \varepsilon v o \varsigma$, this politically charged term not possibly hinting at a sense of shared intellectual endeavor, close and equal footing between the teacher and the disciple, which in turn may reflect upon readers' perception of Alexander's standing as a student of philos-

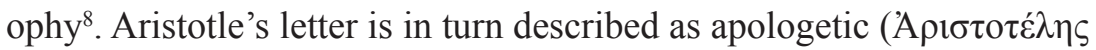

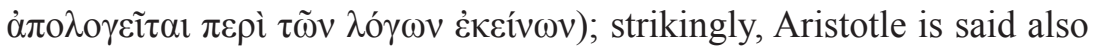

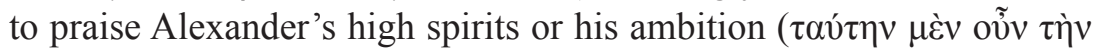

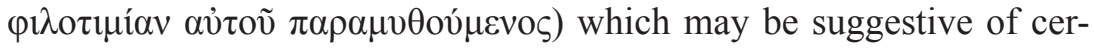
tain respect towards his disciple. Yet, quite likely, it is a reflection of the more general stylistic guidelines applicable when addressing a ruler'. At the first glance this 'community' of letters appears to agree with Plutarch's position concerning the relation between a sage and a ruler ${ }^{10}$, with Aristotle filling the position of educator and advisor: yet, Alexander, that most promising of kings, appears to exceed the expectations owing to his interest in the advanced philosophical schooling: in fact, his interest in what may be regarded 'hard-core' philosophy (if true) may be seen as an obstacle to practical challenges of government ${ }^{11}$.

Next, given that the story follows upon that of the taming of Boucephalus and the account of the intellectual course of his education, the focal point of Plutarch's story as set within the narrative lies in the assertion concerning Alexander's intent to exceed all men in what is best:

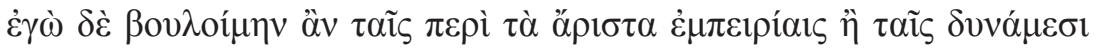
$\delta 1 \alpha \varphi \varepsilon ́ \rho \varepsilon ı v$. Rejecting might and power as such, the young conqueror effectively wishes to be a better man than all others, the supremacy located in the intellectual research rather than anything else. Consequently, the story appears to center on Alexander's virtue, highlighting his desire to excel in intellectual pursuits; yet, at the same time, it

8 This ties up with Plutarch's remark concerning Alexander's inborn qualities: $\tilde{\eta} v$

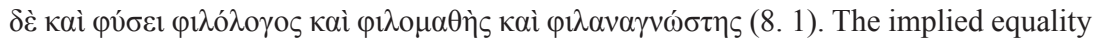
would be all the more striking given Alexander's political stature as the conqueror of Persia.

9 One notes that the subject will become of paramount importance in the account of events leading to Callisthenes' fall from grace and, subsequently, death.

10 On the subject compare e.g. Boulet 2014, Roskam 2002.

11 Van Raalte 2005: 91 cum notis. 
emphasizes the competitive aspect of this particular ambition as Alexander appears to perceive intellectual excellence as yet another tool of dominance. There is also a different undercurrent theme: after all, the story rests upon the assumption of gradation of teaching, of Aristotle keeping some of his doctrines secret, reserving them for his advanced students alone. This, as we well know, appears to be a true account of the activities of the Licaeum: what is striking in Plutarch's account is the sharp divide between the ethical and political treatises (considered epoptic or acroamatic) and the metaphysical investigation, thought to be both intrinsically secret, and crucial to the achievement of perfection sought by Alexander.

The context proves instructive in yet another respect: while chapter 6 of the bios was devoted to the nearly prophetic story of Boucephalus, in chapter 8 Plutarch invokes Alexander's all-consuming admiration of Homer's Ilias (8. 2-4) $)^{12}$. Thus, the exchange of letters is flanked by two tales reflecting Alexander's zealous quest for fame - in a way, in fact, the striking detailedness of the two framing tales appears to eclipse the less colorful narrative of the latter exchange with the Stagirite, thus possibly foreshadowing the later development of Alexander's character: after all, one needs to remember that in the Vitae Plutarch focuses on instruction, the anecdotes being told with an express illustrative purpose: they are chosen for their efficacy in revealing the character of the hero, their ability to reflect his personality ${ }^{13}$. What Plutarch seeks are the signs of the soul $\tau \grave{\alpha} \tau \tilde{\eta} \varsigma \psi v \chi \tilde{\eta} \varsigma$ $\sigma \eta \mu \varepsilon \tilde{\alpha} \alpha$ : as a result, we may rightly suspect that the prominence of the 'heroic' elements in the account of Alexander's formative years, with its inclusion, but also effacement of the intellectual supremacy theme could be read as a foreshadowing of problems to come (as indeed is the slightly self-centered nature of Alexander's preoccupation as he complains that Aristotle may have removed an obstacle banning others from achieving the same intellectual prowess as he had).

\footnotetext{
12 For the presence of epic in the bios cf. Mossman 1988.

13 Compare Alex. 1. 2: For it is not Histories that I am writing, but Lives; and in the most illustrious deeds there is not always a manifestation of virtue or vice, nay, a slight thing like a phrase or jest often makes a greater revelation of character than battles where thousands fall, or the greatest armaments, or sieges of cities (tr. B. Perrin).
} 
Yet, it may be rewarding to consider the nature of the apparent master-student equality: effectively, Alexander is shown to misunderstand Aristotle's actions, an attitude that belies his very ambition (and may be seen as foreshadowing his future rift with the erstwhile tutor). Something troubling appears to lurk in the tale as it is told by Plutarch: the driving force behind Alexander's complaint is his own ambition, not necessarily the perfection of philosophical instruction or even fear that some philosophical doctrines may prove harmful when imparted to an untrained mind. It is almost as if he viewed philosophy as essentially his to command and distribute - after all, he is worried that Aristotle's generosity will enable others to reach the same levels of perfection that he wishes to enjoy.

Once we consider the possible traps of the quoted exchange, it is hardly surprising that Plutarch indicates the complex nature of the later relationship between Alexander and his tutor; while the Cheronean is quick to emphasize that never did Alexander actually harm Aristotle or his school as such, he points out that at some point the relationship was poisoned by mistrust which resulted in a deepening divide between the two men. This is interesting, for the bios effectively portrays Alexander as distancing himself both from his natural father, Philip, and from his 'intellectual' father, Aristotle ${ }^{14}$ : thus, the two relationships mirror each other, the individuality of Alexander overcoming both the biological and the intellectual indebtedness to an authority figure. Yet, even as Aristotle falls into suspicion (8.4), Alexander's affection for philosophy as such remains much in place, testimony of which is his continued admiration for intellectual endeavor. Moreover, he remains manifestly attracted by wisdom, as attested in the gymnosophistae episode or in his association with the Indian Kalanus: however, he distances himself from Aristotle himself. The fall of Callisthenes is an interesting manifestation of this particular duality: for all his respect for free speech, openness, and philosophical study, Alexander is outraged by what he

\footnotetext{
14 According to Plutarch, Alexander was once wont to emphasize the closeness by

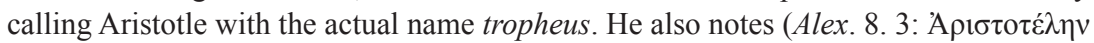

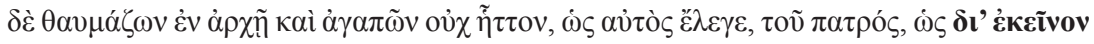

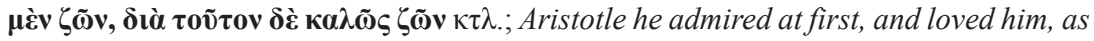
he himself used to say, more than he did his father, for that the one had given him life, but the other had taught him a noble life, Perrin).
} 
perceives as Callisthenes' callousness and disrespect (Alex. 53.4-5, tr. B. Perrin):

And so Callisthenes began his palinode, and spoke long and boldly in denunciation of the Macedonians, and after showing that faction among the Greeks was the cause of the increase of Philip's power, added:

But in a time of sedition, the base man too is in honour.

This gave the Macedonians a stern and bitter hatred of him, and Alexander declared that Callisthenes had given a proof, not of his elo-

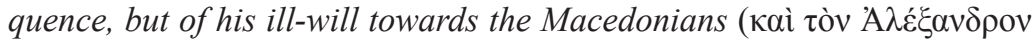

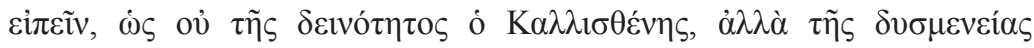

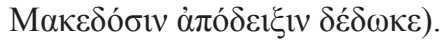

Thus, while Alexander's nobility keeps him from falling victim to an emotion as base as hatred (which in fact invades other Macedonians), he cannot fail but notice that Callisthenes' intellectual proficiency is in a way flawed, that wisdom does not keep him from neglecting propriety. Seen from the outside (Plutarchean) perspective, Callisthenes' behavior may be seen as a proof of his moral failing and, hence, possible unsuitability as a royal advisor: his lack of caution appears as a correlate and outward manifestation of his inability to recognize what is proper (and when it is proper). It may also be taken as symptomatic that the tale appears in the context of a rhetorical display: Callisthenes attempts to speak in utramque as having previously praised the Macedonians he is called upon to speak against them: to be able to speak like this is a proof of technical proficiency, but a proof of extremely questionable nature: only a true philosopher is capable to defend both sides in a discussion without losing his grasp on the truth ${ }^{15}$.

Further, Plutarch portrays the philosopher as notably lacking in $\mathrm{kai}$ ros: it is as if he possessed no practical knowledge how to deal with the Achillean king like Alexander. In the words attributed by the Chaeronean to Aristotle himself (54.2, tr. B. Perrin):

What Aristotle said, then, would seem to have been no idle verdict, namely, that Callisthenes showed great ability as a speaker, but lacked

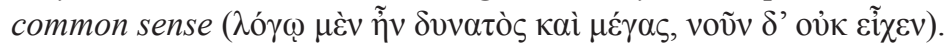

15 For Plutarch's attitude toward rhetorical techne cf. Lauwers 2015: 53-59. 
Thus, Alexander is partly exonerated of the blame stemming from Callisthenes' demise: the opinion of Callisthenes' failings he expressed at the banquet appears almost identical to the one expressed by his former teacher. And while the suspicion he harbors against the Stagirite appears contrary to the received paideia, hence necessarily reflecting on readers' perception of his character, he does not regress to the deplorable levels of tyranny. Even as he fails to appreciate the teachings of his erstwhile master, he resists the temptation of tyranny by maintaining a sympathetic attitude to philosophy as such and never turning to persecution.

\section{HELLENIC IDEOLOGY}

As convincingly argued by Simon Swain, the Plutarchean corpus, but most emphatically the Vitae, furnishes an impressive vehicle for the author's commitment to the Hellenic cause: to give just a small example, the labors of a great Roman general, Marius, may be traced back to his feral nature, but also to his lack of proper education, education which would have been able to contain the inborn ferocity, while the great judicial system of Numa would not have collapsed, were it based on the principles of appropriate education ${ }^{16}$. In the Quaestiones convivales, the Romans are perhaps present, yet relegated to a purely secondary role, the conversation being consistently dependent on the Greek speakers, particularly when matters of particular (philosophical or political) importance are being raised ${ }^{17}$. But what about the Vita Alexandri, one of the most important testimonies to the conqueror's life, the bios of the most important of all Greek leaders? Certainly, the subject offers nearly ideal background for the development of a proHellenic stance: given the possible consequences for our reading of the

16 Swain 2001: 135-186, for Marius cf. Marius, 2; for Numa, Numa 4.12. The question of Plutarch's Hellenism and the related issue of Plutarch's attitude toward Romans and barbarians has remained a frequent object of philological interest, cf. Nikolaidis 1986, Humbert 1991, Fausti 1993, Pelling 1989, Schmidt 1999 and more recently d'Ippolito 2005 and Brechét 2005.

17 Cf. Bartol 2016. 
exchange of letters, perhaps it would be useful to examine this particular aspect of the work.

To have Alexander claim that dispersion of Aristotelian metaphysical concepts runs contrary to his best interest, to portray him as claiming - in the quite possibly most admirable period of his life, before the weaknesses related to alcohol abuse overtook him - that the excellence he seeks is not based on might as such, but on the excellence of the mind as related to philosophy appears important when considering the above-mentioned Hellenic theme (in much similar manner it would be of importance in a reconstruction of Plutarch's general notion of philosophy). Effectively, Plutarch achieves two things in this short passage: first, Alexander, the greatest conqueror of Greek history, an avid student of that most Greek of poets (or rather, of that poet par excellence, Homer) emerges as schooled in philosophy; moreover, his schooling in the latter is said to have extended far beyond the average: this reflects on both Alexander as he is proven erudite and philosophy for it is in a way allowed to claim Alexander (at least the young Alexander) as its own. Second, he claims that the publication of Metaphysics upset Alexander because he saw proliferation of philosophical knowledge as a threat to his superior status, thus furnishing his reader with an image of a perfectly educated Hellenic ruler whose ambition to dominate extends far beyond the military sphere alone. Manifestly, he sees excellence in intellectual endeavor as well, thus appearing to impersonate the fundamental merits of all-round Hellenic education. One notes that even later, as his behavior deteriorates under influence of both eastern customs and overindulgence, he is nevertheless portrayed as taking a lively interest in intellectual discussions, a fact attesting to the permanence of values inculcated in him during the education process (and thus emphasizing the respective value of both the Hellenic and the philosophical education. Perhaps most tellingly, his letter suggests that now that Aristotle's teachings have been made public others may benefit from the education he had, a remark which appears to encapsulate the very essence of his fear: if it is through Aristotle's teachings that he became Alexander: who knows what happens now if its benefits are so easily accessed? Hence, the anxiety may be regarded as reflecting back on the intrinsic value of philosophy as an achievement crucial to 
Alexander's but also to the Greek superiority: undiscrimined dissemination of philosophical ideas may thus be seen as excessive, imprudent, and, ultimately, as a threat to the Greek identity.

\section{CONCLUSIONS}

At a first glance, the exchange of letters concerning Metaphysics appears to have been introduced by Plutarch in order to bolster his own assertions concerning Alexander's impressive education as well as allegations concerning his ambition: even with respect to philosophy, the Macedonian seeks to excel and dominate, to control and to rule. Thus, the exchange may be seen as further emphasizing the agonistic element within the nature of Aristotle's most famous disciple. Still, at the same moment, in having Alexander study (and seek to control) theoretical philosophy may be seen as a literary maneuver highlighting both the Hellenistic origin of philosophy itself and its belonging among the Greek culture: even the greatest of conquerors recognizes the importance, indeed, the glory of the first philosophy. A conqueror par excellence, Plutarch's Macedonian nevertheless shows himself a true disciple of the Stagirite in his concern about excessive dissemination of theoretical knowledge, the latter was originally shared only with the circle of most devoted students; This in fact is the danger which Aristotle appears to have anticipated in advance, and hence avoided through the careful phrasing of his Metaphysics. Both men, the teacher and the pupil, share analogous concerns about the appropriate transmission of philosophical theory, though one may suspect their reasons for doing so may actually differ, Alexander's anxiety stemming principally from his desire to prove himself first in everything he does. Effectively, Plutarch employs the exchange with a twofold aim of commenting both on Alexander's character (hence, contributing to the moral tone of the bios) and on the importance of philosophy (and theoretical philosophy at that) in Greek education. 


\section{BIBLIOGRAPHY}

Baltussen H., 2008, Philosophy and Exegesis in Simplicius: The Methodology of a Commentator, London.

Bartol K., 2015, 'Senecio and Larensis at dinners: two non-Greek intellectuals at the heart of a Hellenic symposion', Classica Cracoviensia 18, pp. 27-37.

Boulet B., 2014, 'The Philosopher-King', [in:] M. Beck (ed.), A Companion to Plutarch, Malden, pp. 449-462.

Brechét Ch., 2008, 'Grecs, Macédoniens et Romains au 'test' d'Homère. Référence homérique et hellénisme chez Plutarque', [in:] A.G. Nikolaidis (ed.), The Unity of Plutarch's Work, Berlin, pp. 85-109.

Fausti D., 1993, 'Lo stereotipo de la superiorità de la cultura greca: la situazione in epoca imperiale attraverso le testimonianze di Plutarco e Galeno', Prometheus 19, pp. 265-277.

Frazier F., 2014, 'The Perils of Ambition', [in:] M. Beck (ed.), A Companion to Plutarch, Malden, pp. 488-502.

Hercher R., 1873, Epistolographi Graeci, Paris.

Hernández Gómez M., 2011, 'La Carta Séptima de Jenofonte y el Agesilao de Plutarco', [in:] J. M. Candau Morón, F.J. Gonzales Ponce, A.L. Chávez Reino (eds.), Plutarco transmissor. Actas del X simposio internacional de la Sociedad Española de Plutarquistas, Sevilla, 12-14 de noviembre de 2009, Universidad de Sevilla, pp. 191-197.

Humbert S., 1991, 'Plutarque, Alexandre et l'Hellénisme', [in:] S. Saïd (ed.),

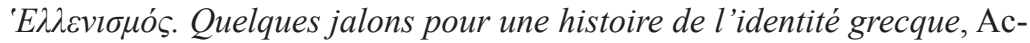
tes de Colloque de Strasbourg (25-27 octobre 1989), Leiden, pp. 169-181.

d'Ippolito G., 2005, 'Filantropia, ellenocentrismo e polietnismo in Plutarco', [in:] A. Pérez Jiménez, F. Titchener (eds.), Historical and Biographical Values of Plutarch's Works. Studies devoted to Professor Philip A. Stadter, Málaga-Utah, pp. 179-195.

Karamanolis G. E., 2006, Plato and Aristotle in agreement? Platonists on Aristotle from Antiochus to Porphyry, Oxford.

Kennedy G.A., 1963, The Art of Persuasion in Greece, Princeton.

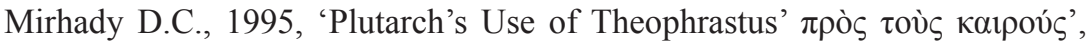
[in:] I. Gallo, B. Scardigli (acd), Teoria e prassi politica nelle opera di Plutarco. Atii del V Convegno plutarcheo, Cartosa di Pontignano, 7-9 giugno 1993, Napoli, pp. 269-273.

Muccioli F., 2011, 'Plutarco, il 'buon uso' delle fonti epigrafiche e il decreto di Temistocle', [in:] J. M. Candau Morón, F.J. Gonzales Ponce, A.L. Chávez Reino (eds.), Plutarco transmissor. Actas del X simposio internacional 
de la Sociedad Española de Plutarquistas, Sevilla, 12-14 de noviembre de 2009, Universidad de Sevilla, pp. 207-222.

Mossman J., 1988, 'Tragedy and Epic in Plutarch's Alexander', JHS 108, pp. 83-93.

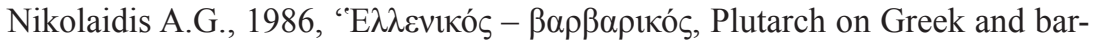
barian characteristics', WS 20, pp. 229-244.

Ottone G., 2011, 'Plutarco trasmissore: ratio e prassi dell citazione nella Vita di Agesilao', [in:] J. M. Candau Morón, F.J. Gonzales Ponce, A.L. Chávez Reino (eds.), Plutarco transmissor. Actas del X simposio internacional de la Sociedad Española de Plutarquistas, Sevilla, 12-14 de noviembre de 2009, Universidad de Sevilla, pp. 223-242.

Pelling Ch., 1989, 'Plutarch: Roman Heroes and Greek culture', [in:] M. Griffin, J. Barnes (eds.), Philosophia Togata, Oxford, pp. 199-232.

Penella R.J., 1979, The Letters of Apollonius of Tyana: A Critical Text with Prolegomena, Translation and Commentary, Leiden.

Prandi L., 2000, 'L'Alessandro di Plutarco. Riflessioni su De Al. Magn. Fort. e su Alex.', [in:] L. van der Stockt (ed.), Rhetorical Theory and Praxis in Plutarch. Acta of the IVth International Congress of the International Plutarch Society, Leuven, July 3-6, 1996, Louvain-Namur, pp. 375-386.

Rosenmeyer P., 2001, Ancient Epistolary Fictions. The Letter in Greek Literature, Cambridge.

Roskam G., 2002, 'A Paideia for a Ruler: Plutarch's Dream of Collaboration between Philosopher and Ruler', [in:] P.A. Stadter, L. Van der Stockt (eds.), Sage and Emperor: Plutarch, Greek Intellectuals, and Roman Power in the Time of Trajan (98-117 A.D.), Leuven, pp. 175-189.

Schettino M.T., 2014, 'The Use of Historical Sources', [in:] M. Beck (ed.), A Companion to Plutarch, Malden, pp. 417-436.

Schmidt Th. S., 1999, Plutarque et les barbares. La rhetorique d'une image, Louvain-Namur.

Swain S., 1990, 'Hellenic culture and Roman heroes of Plutarch', JHS 110, pp. 126-145.

Swain S., 1996, Hellenism and Empire. Language, classicism, and power in the Greek world AD 50-250, Oxford.

Teodorsson S.-T., 2008, 'The Education of Rulers in Theory (Mor.) and Practice (Vitae)', [in:] A.G. Nikolaidis (ed.), The Unity of Plutarch's Work, Berlin, pp. 339-350.

Tirelli A., 1995, 'L'intellettuale e il potere; pedagogia e politica in Plutarco', [in:] I. Gallo, B. Scardigli (eds.), Teoria e prassi politica nelle opera di plutarco. Atii del V Convegno plutarcheo, Cartosa di Pontignano, 7-9 giugno 1993, Napoli, pp. 439-455. 
Van der Stockt L., 2014, 'Compositional Methods in the Lives', [in:] M. Beck (ed.), A Companion to Plutarch, Malden, pp. 321-332.

Van Raalte M., 2005, 'More philosophico: political virtue and philosophy in Plutarch's Lives', [in:] L. de Blois, J. Bons, T. Kessels, D.M. Schenkeveld (eds.), The Statesman in Plutarch's Works, Vol. 2: Greek and Roman Lives, Leiden, pp. 75-112. 